\title{
USE OF IMAGERY AND METAPHOR IN ARAVIND ADIGA'S THE WHITE TIGER
}

\author{
Sushama Kasbekar \\ Assumption University \\ Mail Box 23, Assumption University, Soi 24, \\ Ramkhameng, Bangkok-10240, Thailand \\ sushamakasbekar75@gmail.com
}

\begin{abstract}
This paper focuses on the use of imagery and metaphors in Arvind Adiga's The White Tiger (2008). The writer deliberately and skillfully uses animal imagery and other kinds of metaphors to highlight the intrinsic values of his characters and present themes and characters vividly. This paper highlights how this imagery and metaphor has been used by the writer to bring out the thematic rich and poor divide or the servitude of the poor and overbearing opulence of the rich. The metaphors give added value to the themes and the characters and provide an immediate verbal picture.
\end{abstract}

Keywords: imagery, metaphor, the white Tiger

\begin{abstract}
Makalah ini berfokus pada penggunaan citra dan metafora dalam novel Arvind Adiga The White Tiger (2008). Penulis secara sengaja dan terampil menggunakan citra hewan dan metafora jenis lain untuk menyoroti nilai-nilai intrinsik karakternya dan tema masa kini serta karakter secara jelas. Tulisan ini menyoroti bagaimana citra dan metafora digunakan oleh penulis untuk mengemukakan tema kesenjangan kaya dan miskin atau penghambaan si miskin dan kemewahan yang mendominasi dari si kaya. Metafora memberikan nilai tambah bagi tema-tema tersebut dan para karakternya serta memberikan gambaran lisan langsung.
\end{abstract}

Kata kunci: pencitraan, metafora, The White Tiger 


\section{INTRODUCTION}

The White Tiger was Aravind Adiga's maiden venture which brought him the prestigious Booker prize award in 2008. The book was well received with a platitude of critical acclaim as well as controversy. Manjula Padmanabhan (2008) says that the book is:

"a tedious, unfunny slog, ... compelling, angry and darkly humorous...But is this school boyish sneering the best we can do? Is it enough to paint an ugly picture and then suggest that the way out is to slit the oppressor's throat and become an oppressor oneself?" (Padmanabhan).

While Roy (2008) says, "it is hard to refute that the writer presents a negative picture of the country, but as David Godwin has opined, “It really isn't the job of a writer to be the ambassador for his country. A writer's commitment is to the truth as he sees it", (Roy, 2008, p.4).

Even if do not enter into this controversy, we realize that the book is hard hitting and presents the negative side of the country. Adiga does this both thematically as well as through a generous use of imagery and metaphors. Thematically Adiga draws upon the important rich-poor divide amongst the teeming millions of the fascinating South Asian sub-continent, India. He points out that the rich live in their fabulous homes while the poor are subject to toil and servitude.

When considering imagery in this paper it means: "the formation of mental images, figures or likenesses of things, or of such images collectively," (Dictionary.com). On the other hand, metaphors seek similarity. This similarity is often in one specific respect. Hintikka and Sandhu are of the opinion that: "In order to understand it, the hearer not only has to understand what this similarity is but to realize that there obtains such a similarity. Sometimes the hearer had not been aware of the relevant similarity until the metaphor shocked or otherwise forced him or her to cognizance of it." (Hintikka \& Sandu, 1994, p.178) Therefore the metaphor serves to highlight the similarity and enhances the meaningfulness of the phrase or its components. It embellishes highlights and adds luster. It also startles by its very comparative nature. It is definitely used by writers as a literary device as a mode of creativity.

\section{DISCUSSION}

\section{Jungle, Light and Darkness}

The population of the novel is presented as enmeshed in a jungle. Time and again the novelist refers to India as a "jungle" where Balram Halwai the protagonist has to carve a life for himself. A reference to the jungle is made by the protagonist when he says,

"On the fifteenth of August, 1947 - the day the British left - the cages had been left open; and the animals had attacked and ripped each other apart and jungle law replaced zoo law" (Adiga, 2008, pp.63-4).

This “Orwellian” insight, as opined by Tony D'Souza (2009) is prompted by Adiga's narrative technique which is to present scattered images from the animal kingdom. These images make up the fabric of his tale and present the predicament of the poorer characters fighting the might of the rich ones: When Balram learns to drive the car from an older driver he says,

"The road is a jungle, get it?" 
The reference is not only to the literal road but the road upon which the young Balram is going to tread the journey of life. Balram's story is that of a poor boy from a small village of Laxmangarh in north India. His family sends him to Dhanbad to fend for himself at a tea shop. However, his landlord and mentor take him to Delhi where he learns to drive and serve his master. Balram's life is a life of servitude. He has to serve his master with abject humility both as a driver and a cook.

However, under his outer calm, as he works he realizes the chasm between the rich and the poor. He realizes that to overcome this deep divide he would have to take some drastic action. Meanwhile when he works as a driver for his landlord's son he is forced to take on the blame in an accident. The accident was due to the drunken negligence of his master's westernized wife. His master forces him to accept the blame. However Balram has his revenge when he murders his master to be free for the rest of his life. He leaves Delhi for Bangalore and works as a taxi operator providing cars for those who work at call centers. Soon he has a fleet of 27 cars and proves himself as an entrepreneur.

The metaphor of the "jungle" is juxtaposed with reference to areas of "Light" and "Darkness". The jungle has been described as having a dual personality: and "an area of Darkness" and an area of Light. These are places within India where Balram travels. The India described by the writer is: "two countries in one: an India of Light, and an India of Darkness" (Adiga, 2008, p.14). The India of Light constitutes the wealth, power, technology and knowledge depicted after Balram reaches Delhi and later Bangalore. In the earlier part of the novel is the India of Darkness in the village of Laxmangarh to which Balram belongs and to the mining town of Dhanbad where he works. This is characterized by misery, destitution and illiteracy.

Darkness also includes another significant metaphor: "the black river" (Adiga, 2008, p.14) a reference to the River Ganges. Balram holds the river responsible for bringing darkness to the country. The river is also described as "full of faeces, straw, soggy parts of human bodies, buffalo carrion, and several kinds of industrial acids" (Adiga, 2008, p.15). The River Ganges is revered by the Hindus, the predominant religious sect within the country. It is held to be the daughter of the Vedas, a protector, one who breaks the chain of birth and rebirth. Yet, in the novel the river demarcates the Dark where Balram lives his abject poverty stricken life. Balram is born to poor parents in a tiny hell hole called Laxmangarh in the area of Darkness. He describes his father as stated below:

"My father's spine was a knotted rope, the kind the women use in villages to pull water from wells; the clavicle curved around his neck in high relief, like a dog's collar; cuts and nicks and scars, like little whip marks in his flesh ... The story of a poor man's life is written in his body, in a sharp pen.” (Adiga, 2008, p. 26-27).

\section{The White Tiger}

However, Balram, the protagonist, is different. His personality is like that of the White Tiger. This metaphor used to describe him makes the inspector of schools who visits his village to remark that:

"You, young man, are an intelligent, honest, vivacious fellow in this crowd of thugs and idiots. In any jungle, what is the rarest of animals - the creature that comes along only once in a generation?

"I thought about it and said"

"The white tiger."

“That's what you are, in this jungle” (Adiga, 2008, p.35). 
Thus Balram is set apart as a personality, a White Tiger; one who literally cuts through tremendous odds to become an entrepreneur even if it means murdering his own master. His act makes him a fugitive in Bangalore where he declares: "A White Tiger keeps no friends. It is too dangerous." (Adiga, 2008, p.302). Why did Adiga use this metaphor? He explains:

"I watched him walk behind the bamboo bars. Black stripes and sunlit white fur flashed through the slits in the dark bamboo; it was like watching the slowed down reels of an oldblack-and white film. He was walking in the same line, again and again - from one end of the bamboo bars to the other, then turning around and repeating it over at exactly the same pace, like a thing under a spell” (Adiga, 2008, p.276).

Thus, the metaphor of the White Tiger signifies that Balram, the protagonist and anti-hero in the novel is different, willing to carve a niche for himself to throw off the shackles of poverty, destitution and injustice even though he has to murder his own master. He raises his voice to give vent to his anger at being pushed around and humiliated by people who do everything to crush his sense of urgency. He is particularly outraged at the rich, the authorities, the corrupt police and the law who conspire with the rich to keep the poor in their humble state. Thus, the white tiger or Balram is on a rampage which leads him to some kind of salvation in the form of an entrepreneur in the modern city of Bangalore.

As emphasized by Mendes: "In India's current state of affairs, the cunning and resourceful protagonist posits that there are only two ways that an uneducated and under privileged individual can rise above the restrictions imposed by caste and crime: crime and politics, there are only two destinies in India: either eat or get eaten up” (Adiga, 2008, p.64).

He therefore chooses to prey rather than be the victim. This makes him an anti-hero. This character is central to the story but does not possess any heroic qualities but he becomes the hero because he is the protagonist of the story.

What made Adiga create this kind of protagonist? Adiga's first-hand meeting the poor of India inspired him to create this protagonist: "Many of the Indians I met while I travelled through India blended into Balram; but the character is ultimately of my own invention. I wanted to depict someone from India's underclass - which is perhaps 400 million strong - and which has largely missed out on the economic boom, and which remains invisible in most films and books coming out of India” (Di Martino, 2008).

\section{The Stork, the Raven, and the Buffalo}

Balram is a rough hewn countryman who seeks greener pastures when he realizes that his lot can only be improved if he rebels and does something drastic. This puts him up against his own masters: The have's versus the have-nots. Balram's masters have been metaphorically described as "The Stork", the Buffalo, and Raven etc.:

" The buffalo was one of the landlords in Laxmangarh. There were three others, and each had got his name from the peculiarities of appetite that had been detected in him."

"The Stork was a fat man with a fat moustache, thick and curved and pointy at the tips. He owned the river that flowed outside the village, and he took a cut of every catch of fish caught by every fisherman in the river, and a toll from every boatman who crossed the river to come to our village."

"His brother was called the Wild Boar...."

"The Raven owned the worst land which was the dry...."

"The Buffalo was the greediest of the lot...." (Adiga, 2008, p.24). 
Khan (2009, p. 86) reiterates, "One of the devices of portraying the landlords of the village lies in his use of animal characters which appears close to the art of Orwell in his novel 'The Animal Farm'." This comparison is apt since it portrays the brute and base qualities of the animals personified by the men in the novel.

Further, here the landlords and wealthy businessmen have been depicted as avaricious and exploitative. They are ready to acquire the land of the poor peasant's, take away their prized possessions and always underpay them. Even their women were not spared: they were sexually exploited. Adiga's picture is dark and brings out the exploitative nature of the landlords piercingly.

\section{The Rooster Coop}

"The Rooster Coop" is an extended metaphor used by the writer. As the protagonist writes his fifth letter to the Chinese premier, Wen Jiabao he introduces the Rooster Coop as a place where hundreds of pale hens and brightly colored roosters are stuffed tightly into wire-mesh cages; frightened of impending death from the young butcher. "Yet they do not rebel. They do not try to get out of the coop” (Adiga, 2008, p.173).

This metaphor explains that the Roosters alias subservient servants in the coop never steal their master's money or jewels. The servants are entirely trustworthy and the writer considers it as the basis of the entire Indian economy (Adiga, 2008, p.175). As to why they don't break free of this bondage is explained by the writer as the bonds of the Indian family which trap them to their work. The writer further elaborates:

"Only a man who is prepared to see his family destroyed - hunted, beaten, and burned alive by the masters - can break out of the coop." Balram like other servants tied to the family master was trapped: "I was trapped in the Rooster Coop" (Adiga, 2008, p.179).

Balram however tries hard to break the coop and escape; though his inherent servitude traps him. He knows that he is in the coop because of his abject poverty and if he breaks free his family would be at risk. However when he sees the white tiger at the Delhi zoo pacing up and down he knows that he could emulate him and break free of the shackles constricting him. Finally, the story ends with his breaking the coop when he slits his master's throat with the jagged ends of a broken Whiskey bottle and seeks to become his own master and run an enterprise. He has no remorse about it either: "I'll never say I made a mistake that night. In Delhi, when I slit my master's throat. I'll say it was all worthwhile to know, first for a day, just for an hour, just for a minute, what it means not to be a servant." It is necessary for him to murder his master to be free of the vicious binding of the coop.

\section{Half-Baked Person}

An oft-repeated metaphor is that of a half-baked person, someone who is partially educated. As explained by the by the protagonist:

“ 'The Autobiography of a Half-baked Indian'. That's what I ought to call my life's story. Me, and thousands of others in this country like me, are half-baked because we were never allowed to complete our schooling. Open our skulls, look in with a penlight, and you'll find an odd museum of ideas: sentences of history or mathematics remembered from school textbooks..." (Adiga, 2008, pp.10-11).

Further on the writer emphasizes how his story, the story of a half-baked Indian changes as he makes a big effort to become an entrepreneur. He elaborates that fully formed fellows, after twelve 
years of school and three years of university wear nice suits, join companies but take orders from other men for the rest of their lives. While he, a half-baked fellow, becomes an entrepreneur.

Enjoined to the concept of a half-baked fellow is the parallel of Indian cities and towns which are ill planned and grow haphazardly. Balram, as the new entrepreneur, seeking a new avenue goes through many cities and towns. Most Indian cities and towns are ill planned and the writer draws a metaphoric parallel between the protagonist and the cities and town: both ill planned and half-baked:

"In his journey from village to city, from Laxmangarh to Delhi, the entrepreneur's path crosses any number of provincial towns that have the pollution and noise and traffic of a big city - without any hint of the true city's sense of history, planning and grandeur. Half-baked cities, built for half-baked men." (Adiga, 2008, p.52)

\section{The Great Socialist}

In the earlier part of the story when Balram works at a tea shop in Dhanbad he encounters "The Great Socialist". This metaphor is used forth this politician who is ostensibly a champion of the poor and the downtrodden. His party's symbol is a pair of hands breaking through handcuffs. This symbolizes the poor shaking off the rich. He had ruled the area of Darkness for a long time. Though thoroughly corrupt with 93 criminal cases pending against him he was hand in glove with the judges in the area of Darkness who did not sentence him to prison for his misdeeds since they received overt favors from him. Balram's master and landlord seeks to unseat the politician, the Great Socialist from power, but he cannot pit himself against this corrupt ruthless man who, on the one hand pretends to be a champion of the poor and on the other has amassed a fortune for himself salted away in a safe locker in a Swiss Bank.

The poor, whom the Great Socialist professes to help, voted for him because he was superior to their masters. The masters and landlords had to bow to him: "That was the positive side of the Great Socialist. He humiliated all our masters - that's why we kept voting him back in.” (Adiga, 2008, p.105). This politician has been skillfully drawn as a socialist, a champion of the poor whom he paradoxically exploits to maintain his own power. The metaphor paradoxically explains his ruthless side, for he is neither "great' nor a 'socialist'.

\section{CONCLUSION}

Adiga has therefore tried to present his characters with the use of metaphors. These metaphors embellish, but they add more meaning subtlety and insidiously. They are often scathing, adding gore to this tale of deprivation and poverty. This technique is by no means new or unique: "Indians, in particular are accustomed to the art of employing imagery in their conversational deliverance or philosophical deliberations: "Talking metaphorically or obliquely by implication is generally natural with Indians'” (Poonkodi, p.186). Though the novel has been variously criticized for being iconoclastic, bringing the negative side of India to the fore it is a commendable effort to voice the grievances of the under-privileged and poorer sections of society. The writer has certainly used fascinating imagery and metaphors to embellish his scintillating tale. 


\section{REFERENCES}

Adiga, A. (2008). The White Tiger. Noida: Harper Collins Publishers and India Today Group.

Espy, W. R. (1983). The Garden of Eloquence. New York: Harper and Row.

Di Martino, N. (2008). Interview with Aravind Adiga. Retrieved 18 November 2011 from http://universitybookstore.blogspot.com/2008/10/nick-interviews-aravind-adiga.html.

Hintikka,J., \& Sandu, G. (1994). Aspects of the Metaphor. Netherlands: Kluwer Academic Publishers, Martinus Nijhoff Publishers.

Khan, M. Q. (2009). The White Tiger: A Critique, (vol.1, no.2). Retrieved 182011 from http://www.inflibnet.ac.in/ojs/index.php/JLCMS/article/viewFile/34/32.

Mendes, A. C. (2010). Exciting Tales of Exotic Dark India: Adiga's The White Tiger. Retrieved 29 November 2010 from http://www.jcl.sagepub.com/content/45/2/275

Poonkodi, M. (2009). The Voice of Servility and Dominance Expressed through Animal Imagery in Adiga's The White Tiger. Language in India, 9 (11).

Padmanabhan, Manjula (2008). The Outlook, India. Retrieved 1 November 2008 from http://www.outlook.com/Fulli.asp?Fodname-20081014xFname-Books \& Sid - 188888.

Roy, Amit. (2008). Aravinda Adiga wins ‘God’ of Agents. The Telegraph. October, 2008, p.4 